\title{
Chemical composition, nutritional value and antioxidant properties of Mediterranean okra genotypes in relation to harvest stage
}

\author{
Spyridon Petropoulos ${ }^{\mathrm{a}, *}$, Ângela Fernandes ${ }^{\mathrm{b}}$, Lillian Barros ${ }^{\mathrm{b}}$, Isabel C.F.R. Ferreira ${ }^{\mathrm{b}, *}$ \\ a Universityof Thessaly, Department of Agriculture, Crop Production and Rural Environment, 38446 N. Ionia, Magnissia, Greece \\ b Centrode Investigação de Montanha (CIMO), Instituto Politécnico de Bragança, Campus de Santa Apolónia, 5300-253 Bragança, Portugal
}

\section{A R T I C L E I N F O}

\section{Keywords:}

Abelmoschus esculentus

Antioxidant activity

Fatty acids

Local landraces

Mineral content

Organic acids

Proximate analysis

Tocopherols

\begin{abstract}
A B S T R A C T
The aim of the present study was to determine the effect of fruit size on nutritional value, chemical composition and antioxidant properties of Mediterranean okra genotypes. For this purpose, pods from four okra cultivars and local landraces commonly cultivated in Greece, as well as pods from four commercial cultivars from North America were collected at two sizes $(3-5$ and $>7 \mathrm{~cm})$. Significant differences were observed between the studied genotypes for both nutritional value and chemical composition parameters. Small fruit had a higher nutritional value, whereas chemical composition differed in a genotype dependent manner with most of the studied cultivars showing better results when harvested in small size. In conclusion, fruit size has a genotype dependent impact on chemical composition and nutritional value of okra pods and the common practice of harvesting okra fruit while they still have a small size helps to increase nutritional value for most of the studied genotypes.
\end{abstract}

\section{Introduction}

Okra (Abelmoschus esculentus L. Moench.) is a vegetable native to the tropical and subtropical regions of the world, that belongs to Malvaceae family and is usually consumed for its edible immature fruit in fresh or dried form, although its leaves and seeds are also edible with less common use (Adetuyi \& Osagie, 2011; Camciuc, Deplagne, Vilarem, \& Gaset, 1998). Apart from edible use, extracts from okra fruit have been used for various applications in the food and pharmaceutical industry as emulsifiers, drug tablet formulations or blood plasma replacement, due to their high content in biopolymers, such as polysaccharides (mainly pectins), and bioactive compounds such as ascorbic acid and beta-carotene (Adetuyi \& Osagie, 2011; Arlai, Nakkong, Samjamin, \& Sitthipaisarnkun, 2012; Ghori, Alba, Smith, Conway, \& Kontogiorgos, 2014).

Its origins are believed to come from East and/or South Africa, India or South-East Asia (Siemonsma, 1982). Nowadays, it is widespread throughout the world, while in Europe its cultivation and consumption is more common around the Mediterranean basin, and especially Cyprus, Egypt, Greece, and Turkey where it is a basic ingredient in many local and traditional dishes (Çalişir, Özcan, Haciseferoğullari, \& Yildiz, 2005). In Greece and Turkey, they are considered as minor vegetable crops, however they are important vegetable species and the small immature fruit are very popular in various summer dishes (Çalişir et al., 2005).

The nutritional value of immature pods is highly appreciated from consumers, since okra fruit are considered a rich source of dietary fibers, carbohydrates, vitamins and minerals (Adetuyi \& Osagie, 2011; Gemede, Ratta, Haki, \& Woldegiorgis, 2014); however, high variation in proximate and chemical composition has been reported between various okra accessions (Gemede, Haki, Beyene, Woldegiorgis, \& Rakshit, 2016) and different growing conditions (Makhadmeh \& Ereifej, 2004), while harvest stage may also affect chemical composition of immature pods (Piloo \& Kabir, 2011). Okra fruit also present significant antioxidant properties, mostly due to their high content in vitamin C, carotenoids and flavonoids (Gemede et al., 2014), as well as therapeutic properties against diabetes, hyperlipidaemia, microbes, ulcers and neurodegenerative diseases (Atawodi et al., 2009; Kamalesh, Subrata, Asraf, \& Pranabesh, 2016; Mishra, Kumar, \& Rizvi, 2013). Apart from nutrients and beneficial health compounds, okra pods may also contain anti-nutrients such as phytates, oxalates and saponins which affect bioavailability of minerals $(\mathrm{Ca}, \mathrm{Fe}$ and $\mathrm{Zn}$ ) and limit nutritional value of the fruit (Adetuyi \& Osagie, 2011; Gemede et al., 2016).

There are many Greek cultivars and local landraces that according to Koutsos, Koutsika-Sotiriou, Gouli-vavdinoudi, and Tertivanidis

\footnotetext{
* Corresponding authors at: University of Thessaly, School of Agricultural Sciences, Fytokou Street, 38446 N. Ionia, Magnissia, Greece (S.A. Petropoulos). Polytechnic Institute of Bragança, Campus de Santa Apolónia, 1172, 5300-253 Bragança, Portugal (I.C.F.R. Ferreira).

E-mail addresses: fangio57gr@gmail.com (S. Petropoulos), iferreira@ipb.pt (I.C.F.R. Ferreira).
} 
(2000) are closely related with Turkish cultivars that were imported from immigrants and were artificially selected and adapted to specific agro-climatic conditions throughout the years. In the past few years, there used to be many Greek okra cultivars, including cv. "Pylaea", "Boyati", "Veloudo", "Lasithi", "Pentagoni" and so forth; however nowadays the only Greek cultivar that its seeds are commercially available is cv. "Pylaea", while for the rest of the cultivars only small amounts are available, mainly from seeds kept from growers own production from year to year. In addition, Koutsos et al. (2000) have reported that cv. "Boyati" and "Veloudo" probably have the same origin and separated after cultivation at different regions and growers selection.

In the Mediterranean basin, okra fruit is harvested and consumed as soon as it reaches a length of $3-5 \mathrm{~cm}$. However, in other markets of the world and especially in North America where different genotypes are cultivated, the acceptable fruit size is bigger $(7-12 \mathrm{~cm}$ or larger, depending on the cultivar), provided that lignification of fruit walls and seed formation has not started. Considering the newly introduced Northern America cultivars in European markets where consumers are used to consume small-sized fruit, the aim of the present study was to evaluate chemical composition of okra fruit at two marketable sizes (3-5 and $>7 \mathrm{~cm}$ ), as well as to compare the quality features of the main okra genotypes cultivated in Greece with genotypes of foreign origin.

\section{Materials and methods}

\subsection{Plant material}

Okra pods were collected from plants grown from seeds, including seeds of four Greek okra (Abelmoschus esculentus L.) genotypes [three cultivars registered in the national catalogue of vegetable crops (cvs. "Boyati", "Pylaea" and "Veloudo") obtained from Greek Gene bank (Agricultural Research Center of Macedonia and Thraki, National Agricultural Research Foundation, Thessaloniki, Greece) and one local landrace ("Lasithi") from the seed collection of Laboratory of Vegetables Production, University of Thessaly, Greece]. In addition, seeds of four commercial cultivars from North America [cv. "Choppee" (heirloom variety; Southern Exposure Seed Exchange, VA, USA), "Clemson Spineless" (commercial cultivar; Park Seed Co., SC, USA), "Dwarf Long Green" (variety; Victory Seed Co., OR, USA) and "Silver Queen" (heirloom variety; Park Seed Co., SC, USA)] were obtained from seed companies. Seeds from each genotype were put in seed trays containing peat on April 14th, 2016 and transferred in a nursery on heated beds $\left(20^{\circ} \mathrm{C}\right)$, while young seedlings (stage of 3 true leaves) were transplanted in the field on May 11th, 2016 in a plant density of 25,000 plants $\mathrm{ha}^{-1}(0.8 \mathrm{~m}$ between rows and 0.5 within each row). For each genotype and each treatment (fruit size), 18 plants were used (36 plants per genotype and 160 plants in total). Experiments were carried out at the experimental field of the University of Thessaly in Velestino, Greece.

Pods were harvested at two growth stages depending on their length, namely $3-5 \mathrm{~cm}$ and $>7 \mathrm{~cm}$ in order to simulate different market standards. For large-sized fruit, trial harvests took place in order to define the size were pods from each genotype lose marketability (inedible fruit due to thick pod walls and seed formation). In any case, only marketable fruit were considered for further analyses. The first pods were collected on June 22nd, 2016 (genotype "Lasithi") and harvests continued at regular intervals for one month period in order to avoid differences in chemical composition due to variability in growing conditions and position of pods on the plant. After each harvest, pods were cleaned with distilled water, dried with absorbent paper and cut into small pieces after discarding peduncle and calyx. Cut pods were put in sealed bags and stored in freezing conditions $\left(-20^{\circ} \mathrm{C}\right)$. When harvest for each treatment was completed, all fruit from the same treatment were put together in batch samples, freeze dried and stored in deep freezing conditions $\left(-80^{\circ} \mathrm{C}\right)$ until chemical analyses took place.

Seed collections for all the tested genotypes are deposited in the Laboratory of Vegetable Production, University of Thessaly, Greece.

\subsection{Chemical composition}

\subsubsection{Nutritional value}

All pod samples were analysed in terms of macronutrients (moisture, proteins, fat, carbohydrates and ash), according to the AOAC procedures (AOAC, 2016). Crude protein content (Nx6.25) was estimated using the macro-Kjeldahl method; Soxhlet extraction with petroleum ether was used to determine the crude fat content; incineration at $600 \pm 15{ }^{\circ} \mathrm{C}$ was used to measure ash content. Total carbohydrates were calculated by difference and the energetic value was calculated as following: Energy $(\mathrm{kcal})=4 \times(\mathrm{g}$ protein $+\mathrm{g}$ carbohydrate $)+9 \times$ ( $\mathrm{g}$ fat).

For mineral composition analysis, samples of fresh pods were dried in a forced-air oven at $72{ }^{\circ} \mathrm{C}$ to constant weight, ground to powder, subjected to dry ashing and extracted with $1 \mathrm{~N} \mathrm{HCl}$ to determine the mineral. $\mathrm{Ca}, \mathrm{Mg}, \mathrm{Fe}, \mathrm{Mn}, \mathrm{Zn}$, and $\mathrm{Cu}$ content were determined by atomic absorption spectrophotometry (Perkin Elmer $1100 \mathrm{~B}$, Waltham, MA), and $\mathrm{Na}$ and $\mathrm{K}$ content by flame photometry (Sherwood Model 410, Cambridge, UK).

\subsubsection{Free sugars}

Free sugars were determined by HPLC coupled to a RI detector (Knauer, Smartline system 1000, Berlin, Germany) using the internal standard (IS, melezitose, Sigma-Aldrich, St. Louis, MO, USA) method, as previously described by Barros, Pereira, Calhelha, et al. (2013). Mobile phase consisted of acetonitrile:water mixture $(70: 30 \mathrm{v} / \mathrm{v}$, acetonitrile HPLC-grade, Lab-Scan, Lisbon, Portugal) and separation was achieved using a Eurospher 100-5 NH2 column $(4.6 \times 250 \mathrm{~mm}, 5 \mu \mathrm{m}$, Knauer). The results were recorded and processed using Clarity 2.4 software (DataApex, Prague, Czech Republic).

\subsubsection{Organic acids}

Organic acids were determined by ultra-fast liquid chromatography (UFLC) (Shimadzu 20 A series UFLC, Shimadzu Corporation, Kyoto, Japan) coupled to a diode-array detector (DAD) operating in the conditions described by Barros, Pereira, and Ferreira (2013). The compounds were identified and quantified by comparing the area of sample' peaks recorded at $215 \mathrm{~nm}$ with calibration curves obtained from commercial standards (Sigma-Aldrich, St. Louis, MO, USA). The results were recorded and processed using LabSolutions Multi LC-PDA software (Shimadzu Corporation, Kyoto, Japan).

\subsubsection{Tocopherols}

Tocopherols were determined following a procedure previously described by Barros, Pereira, Calhelha, et al. (2013), using a HPLC system (Knauer, Smartline system 1000, Berlin, Germany) coupled to a fluorescence detector (FP-2020; Jasco, Easton, USA) programmed for excitation at $290 \mathrm{~nm}$ and emission at $330 \mathrm{~nm}$, using the IS (tocol, Matreya, Pleasant Gap, PA, USA) method for quantification. Mobile phase consisted of a mixture of hexane:ethyl acetate (70:30, v/v, hexane and ethyl acetate HPLC-grade, Lab-Scan, Lisbon, Portugal), and chromatographic separation was performed using a Polyamide II column $(250 \times 4.6 \mathrm{~mm}, 5 \mu \mathrm{m}$; YMC, Kyoto, Japan). The results were recorded and processed using Clarity 2.4 software (DataApex, Prague, Czech Republic).

\subsubsection{Carotenoids and chlorophyll}

A fine dried powder $(150 \mathrm{mg})$ of the lyophilized material was vigorously shaken with $10 \mathrm{~mL}$ of acetone-hexane mixture (4:6) for $1 \mathrm{~min}$ and filtered through Whatman No. 4 filter paper. The absorbance of the filtrate was measured at 453, 505, 645 and $663 \mathrm{~nm}$ (Nagata \& Yamashita, 1992). Content of beta-carotene was calculated 
Table 1

Nutritional value $\left(\mathrm{g} 100 \mathrm{~g}^{-1} \mathrm{fw}\right)$ and energetic value (kcal $100 \mathrm{~g}^{-1} \mathrm{fw}$ ) of the studied okra fruits (mean $\pm \mathrm{SD}$ ).

\begin{tabular}{|c|c|c|c|c|c|c|c|}
\hline Fruit size & Genotype & Moisture & Fat & Proteins & Ash & Carbohydrates & Energy \\
\hline \multirow[t]{8}{*}{ Small } & Lasithi & $85.6 \pm 0.6 \mathrm{~d}(\mathrm{~b})$ & $0.28 \pm 0.01 c(a)$ & $2.68 \pm 0.01 \mathrm{~d}(\mathrm{a})$ & $0.85 \pm 0.01 b(a)$ & $10.6 \pm 0.005 c(a)$ & $55.67 \pm 0.06 c(a)$ \\
\hline & Pylaea & $86.1 \pm 0.5 \mathrm{~cd}(\mathrm{a})$ & $0.279 \pm 0.003 c(a)$ & $2.77 \pm 0.08 c(a)$ & $0.84 \pm 0.04 \mathrm{~b}(\mathrm{a})$ & $10.0 \pm 0.1 \mathrm{e}(\mathrm{a})$ & $53.8 \pm 0.1 \mathrm{~d}(\mathrm{a})$ \\
\hline & Boyati & $83.9 \pm 0.7 \mathrm{e}(\mathrm{a})$ & $0.321 \pm 0.001 \mathrm{a}(\mathrm{a})$ & $2.942 \pm 0.003 \mathrm{~b}(\mathrm{a})$ & $0.971 \pm 0.006 \mathrm{a}(\mathrm{a})$ & $11.9 \pm 0.001 \mathrm{~b}(\mathrm{~b})$ & $62.29 \pm 0.02 b(b)$ \\
\hline & Veloudo & $80.8 \pm 0.5 f(a)$ & $0.302 \pm 0.001 \mathrm{~b}(\mathrm{a})$ & $3.44 \pm 0.04 a(a)$ & $0.97 \pm 0.03 a(a)$ & $14.5 \pm 0.05 \mathrm{a}(\mathrm{b})$ & $74.6 \pm 0.1 \mathrm{a}(\mathrm{b})$ \\
\hline & Choppee & $87.0 \pm 0.3 \mathrm{bc}(\mathrm{b})$ & $0.177 \pm 0.004 \mathrm{~d}(\mathrm{a})$ & $2.415 \pm 0.001 \mathrm{e}(\mathrm{a})$ & $0.77 \pm 0.02 \mathrm{~d}(\mathrm{a})$ & $9.6 \pm 0.01 f(a)$ & $49.70 \pm 0.01 \mathrm{f}(\mathrm{a})$ \\
\hline & Dwarf Long Green & $86.6 \pm 0.1 c(b)$ & $0.144 \pm 0.001 \mathrm{e}(\mathrm{a})$ & $2.26 \pm 0.01 f(a)$ & $0.81 \pm 0.02 c(a)$ & $10.2 \pm 0.01 \mathrm{~d}(\mathrm{a})$ & $51.02 \pm 0.04 \mathrm{e}(\mathrm{a})$ \\
\hline & Silver Queen & $87.8 \pm 0.1$ bcd(a) & $0.139 \pm 0.001 \mathrm{e}(\mathrm{a})$ & $2.25 \pm 0.03 f(a)$ & $0.77 \pm 0.01 \mathrm{~d}(\mathrm{a})$ & $9.1 \pm 0.02 \mathrm{~g}(\mathrm{a})$ & $46.51 \pm 0.02 \mathrm{~g}(\mathrm{a})$ \\
\hline & Clemson Spineless & $89.1 \pm 0.8 \mathrm{a}(\mathrm{b})$ & $0.182 \pm 0.004 \mathrm{~d}(\mathrm{a})$ & $1.88 \pm 0.02 \mathrm{~g}(\mathrm{a})$ & $0.66 \pm 0.01 \mathrm{e}(\mathrm{a})$ & $8.2 \pm 0.01 \mathrm{~h}(\mathrm{a})$ & $41.83 \pm 0.04 \mathrm{~h}(\mathrm{a})$ \\
\hline Fruit size & Genotype & Moisture & Fat & Proteins & Ash & Carbohydrates & Energy \\
\hline \multirow[t]{8}{*}{ Large } & Lasithi & $88.6 \pm 0.6 b(a)$ & $0.188 \pm 0.002 \mathrm{c}(\mathrm{b})$ & $1.90 \pm 0.04 \mathrm{e}(\mathrm{b})$ & $0.62 \pm 0.04 \mathrm{~d}(\mathrm{~b})$ & $8.7 \pm 0.1 \mathrm{~d}(\mathrm{~b})$ & $44.0 \pm 0.1 \mathrm{~d}(\mathrm{~b})$ \\
\hline & Pylaea & $86.9 \pm 0.2 c(a)$ & $0.175 \pm 0.003 \mathrm{~d}(\mathrm{~b})$ & $2.27 \pm 0.02 c(b)$ & $0.79 \pm 0.01 b(a)$ & $9.90 \pm 0.03 c(a)$ & $50.26 \pm 0.02 c(b)$ \\
\hline & Boyati & $83.1 \pm 0.8 \mathrm{~d}(\mathrm{~b})$ & $0.194 \pm 0.007 \mathrm{~b}(\mathrm{~b})$ & $2.82 \pm 0.03 \mathrm{~b}(\mathrm{~b})$ & $0.949 \pm 0.005 \mathrm{a}(\mathrm{b})$ & $13.0 \pm 0.1 b(a)$ & $64.88 \pm 0.04 \mathrm{~b}(\mathrm{a})$ \\
\hline & Veloudo & $80.1 \pm 0.4 \mathrm{e}(\mathrm{b})$ & $0.206 \pm 0.004 \mathrm{a}(\mathrm{b})$ & $2.91 \pm 0.02 \mathrm{a}(\mathrm{b})$ & $0.10 \pm 0.04 \mathrm{a}(\mathrm{a})$ & $15.8 \pm 0.01 \mathrm{a}(\mathrm{a})$ & $76.7 \pm 0.1 \mathrm{a}(\mathrm{a})$ \\
\hline & Choppee & $89.0 \pm 0.5 b(a)$ & $0.153 \pm 0.003 \mathrm{e}(\mathrm{b})$ & $1.98 \pm 0.04 \mathrm{~d}(\mathrm{~b})$ & $0.61 \pm 0.01 \mathrm{~d}(\mathrm{~b})$ & $8.26 \pm 0.02 f(b)$ & $42.34 \pm 0.01 \mathrm{e}(\mathrm{b})$ \\
\hline & Dwarf Long Green & $89.1 \pm 0.4 b(a)$ & $0.138 \pm 0.001 \mathrm{f}(\mathrm{b})$ & $1.641 \pm 0.005 \mathrm{f}(\mathrm{b})$ & $0.64 \pm 0.02 \mathrm{~cd}(\mathrm{~b})$ & $8.50 \pm 0.01 \mathrm{e}(\mathrm{b})$ & $41.8 \pm 0.1 \mathrm{f}(\mathrm{b})$ \\
\hline & Silver Queen & $89.1 \pm 0.4 b(a)$ & $0.127 \pm 0.003 \mathrm{~g}(\mathrm{~b})$ & $1.89 \pm 0.02 \mathrm{e}(\mathrm{b})$ & $0.67 \pm 0.01 \mathrm{c}(\mathrm{b})$ & $8.24 \pm 0.01 f(b)$ & $41.67 \pm 0.04 f(b)$ \\
\hline & Clemson Spineless & $91.3 \pm 0.5 \mathrm{a}(\mathrm{a})$ & $0.177 \pm 0.006 \mathrm{~d}(\mathrm{a})$ & $1.37 \pm 0.03 g(b)$ & $0.50 \pm 0.01 \mathrm{e}(\mathrm{b})$ & $6.68 \pm 0.02 \mathrm{~g}(\mathrm{~b})$ & $33.77 \pm 0.05 \mathrm{~g}(\mathrm{~b})$ \\
\hline
\end{tabular}

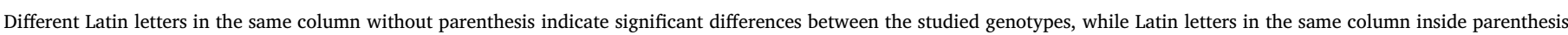
refer to comparisons between fruit sizes of the same genotype according to Tukey's HSD test ( $\mathrm{p}=0.05$ ).

* S: small size fruit $(3-5 \mathrm{~cm})$; L: Large size fruit $(>7 \mathrm{~cm})$.

according to the following equation:

$$
\begin{aligned}
\text { beta-carotene }(\mathrm{mg} / 100 \mathrm{~mL})= & 0.216 \times \mathrm{A}_{663}-1.220 \times \mathrm{A}_{645}-0.304 \times \mathrm{A}_{505} \\
& +0.452 \times \mathrm{A}_{453} ; \mathrm{lycopene}(\mathrm{mg} / 100 \mathrm{~mL}) \\
= & -0.0458 \times \mathrm{A}_{663}+0.204 \times \mathrm{A}_{645}-0.304 \times \mathrm{A}_{505} \\
& +0.452 \times \mathrm{A}_{453} ; \text { chlorophyll } a(\mathrm{mg} / 100 \mathrm{~mL}) \\
= & 0.999 \times \mathrm{A}_{663}-0.0989 \times \mathrm{A}_{645} ; \text { chlorophyll } b(\mathrm{mg} / 100 \mathrm{~mL}) \\
= & -0.328 \times \mathrm{A}_{663}+1.77 \times \mathrm{A}_{645} \text {, and further expressed in mg } \\
& / 100 \text { g of fresh weight. }
\end{aligned}
$$

\subsubsection{Fatty acids}

The fatty acids were identified using a gas chromatographer (DANI1000, Contone, Switzerland) provided with a split/splitless injector and a flame ionization detector (GC-FID at $260{ }^{\circ} \mathrm{C}$ ) operating in the conditions described by Barros, Pereira, Calhelha, et al. (2013). The identification and quantification of the present fatty acids (fatty acid methyl esters (FAME) reference standard mixture 37, Sigma-Aldrich, St. Louis, MO, USA) was achieved by comparing the relative retention times of FAME standard with the ones of the sample' compounds. The results were recorded and processed using CSW 1.7 software (Data Apex 1.7, Prague, Czech Republic).

\subsubsection{Antioxidant activity}

Antioxidant activity and bioactive compounds were assessed according to methods previously reported by Barros, Pereira, Calhelha, et al. (2013). Methanol/water (80:20, $v / v)$ extracts were obtained from the lyophilized material. Each sample $(1 \mathrm{~g})$ was extracted twice by stirring $\left(25^{\circ} \mathrm{C}\right.$ at $\left.150 \mathrm{rpm}\right)$ with $30 \mathrm{~mL}$ of methanol/water $(80: 20, v / v)$ for $1 \mathrm{~h}$ and subsequently filtered through a Whatman No. 4 paper. The combined methanol/water extracts were evaporated at $40{ }^{\circ} \mathrm{C}$ (rotary evaporator Büchi R-210, Flawil, Switzerland) to remove the methanol and further frozen and lyophilized. The extracts were redissolved in methanol/water $(80: 20, v / v)$ at a final concentration of $50 \mathrm{mg} / \mathrm{mL}$ and further diluted to different concentrations to be submitted to the distinct in vitro assays.

DPPH radical-scavenging activity was evaluated by using an ELX800 microplate reader (Bio-Tek Instruments, Inc; Winooski, VT, USA), and calculated as a percentage of DPPH discolouration using the formula: $\left[\left(A_{D P P H}-A_{S}\right) / A_{D P P H}\right] \times 100$, where $A_{S}$ is the absorbance of the solution containing the sample at $515 \mathrm{~nm}$, and $A_{\mathrm{DPPH}}$ is the absorbance of the DPPH solution. Reducing power was evaluated by the capacity to convert $\mathrm{Fe}^{3+}$ to $\mathrm{Fe}^{2+}$, measuring the absorbance at $690 \mathrm{~nm}$ in the microplate reader mentioned above. Inhibition of $\beta$-carotene bleaching was evaluated though the $\beta$-carotene/linoleate assay; the neutralization of linoleate free radicals avoids $\beta$-carotene bleaching, which is measured by the formula: $\beta$-carotene absorbance after $2 \mathrm{~h}$ of assay/initial absorbance) $\times 100$. Lipid peroxidation inhibition in porcine (Sus scrofa) brain homogenates was evaluated by the decreasing in thiobarbituric acid reactive substances (TBARS); the colour intensity of the malondialdehyde-thiobarbituric acid (MDA-TBA) was measured by its absorbance at $532 \mathrm{~nm}$; the inhibition ratio (\%) was calculated using the following formula: $[(\mathrm{A}-\mathrm{B}) / \mathrm{A}] \times 100 \%$, where $\mathrm{A}$ and $\mathrm{B}$ were the absorbance of the control and the sample solution, respectively (Barros, Pereira, Calhelha, et al. (2013)). The results were expressed in $\mathrm{EC}_{50}$ values (sample concentration providing $50 \%$ of antioxidant activity or 0.5 of absorbance in the reducing power assay) for antioxidant activity and Trolox was used as a positive control.

\subsubsection{Statistical analysis}

The experiment was laid according to Randomized Complete Blocks design $(n=6)$ with three replications. Three samples were analyzed for each treatment (fruit size and genotype), while all the assays were carried out in triplicate. Results were expressed as mean values and standard deviations (SD), and analyzed using one-way analysis of variance (ANOVA) followed by Tukey's HSD Test with $\mathrm{p}=0.05$. This analysis was carried out using Statgraphics 5.1.plus (Statpoint Technologies, Inc., VA, USA).

\section{Results and discussion}

Proximate composition of the studied okra genotypes in relation to fruit size are presented in Table 1. Carbohydrates were the most abundant macronutrients, regardless of fruit size, having a major contribution to calorific value of okra fruit, whereas proteins, fat and ash were detected in lower amounts. Moreover, protein content of okra fruit is very high comparing to other fresh vegetables with a contribution to total calorific value between the range of $18.0-20.8$ and $15.1-18.9 \%$, for small and large fruit respectively, as already reported by Adetuyi and Osagie (2011), suggesting plant pods could serve as a good source of protein in human diet. Nutritional value is significantly affected by fruit size, where in most cases macronutrients content decreased or remained unchanged when fruit harvested at a later stage. The only cases where increase was observed was for carbohydrates and energy 
content of cv. "Boyati" and "Veloudo", with larger fruit containing more carbohydrates and have a higher calorific value than smaller fruit. Similar results regarding ash content have been reported by Olivera, Mugridge, Chaves, Mascheroni, and Viña (2012), who also reported a decreasing trend for "Clemson spineless" and up to the size of 7-8 cm, while Piloo and Kabir (2011) have suggested that pods retain their market quality when harvested up to $4-5$ days after fruit set, which is usually the case in the Mediterranean basin. Moreover, Longe, Fetuga, and Aken'ova (1982) who studied proximate composition of okra pods harvested at 1, 4, 7 and 10 days after fruit set, have reported that crude protein and free sugars content decreased with age, although significant differences between the studied varieties were observed. Therefore, the market standards that are applicable to European markets, e.g. smallsized fruit, are beneficial to nutritional value of pods; however, this practice should be genotype related, since two commonly cultivated genotypes of the Mediterranean basin ("Boyati" and "Veloudo") showed a different trend for carbohydrates content and harvesting larger fruit should be considered for highest carbohydrates content.

Fruit of cv. "Veloudo" had the highest sugar, protein, ash and energy content at both sizes, while fat content was the highest in cv. "Boyati" and "Veloudo" for small and large size fruit, respectively. In contrast, cv. "Clemson Spineless" had the lowest content for all the nutritional parameters, except for fat content where cv. "Silver Queen" showed the lowest amounts. These differences could be partly associated with differences in moisture content of fruit, as well as to differences in genetic potential between the studied genotypes. Gemede et al. (2016), have also reported differences in proximate analysis of various okra accessions pods, while the nutrients amounts were in the same range with the results reported in the present study. The only exception was observed in carbohydrates content which were detected in higher amounts in our study, comparing to the results of Gemede et al. (2016).

Okra pods are rich in minerals such as $\mathrm{Ca}, \mathrm{K}$ and $\mathrm{Mg}$, while they also contain significant amounts of trace elements such Fe, $\mathrm{Zn}$ and $\mathrm{Mn}$. Minerals content differed significantly among the studied genotypes and fruit sizes (Table 2). Ca and Mg content increase with fruit size only in the case of cv. "Boyati", "Veloudo", "Choppee" and "Dwarf Long Green", while Mn content increased for all the genotypes and K content was not affected by fruit size. The reported minerals content in okra pods shows great variation (Adetuyi \& Osagie, 2011; Gemede et al., 2016; Makhadmeh \& Ereifej, 2004; Olivera et al., 2012), while it also differs significantly with that in our study, which could be probably attributed to differences in the tested genotypes. In contrast, Dos Santos et al. (2013) have reported similar amounts of $\mathrm{Ca}, \mathrm{K}, \mathrm{Mg}$ and $\mathrm{Zn}$ in okra pods collected in Brazil. Olivera et al. (2012) have also reported a genotype depended effect of fruit size on mineral content $(\mathrm{Ca}, \mathrm{Mg}, \mathrm{K}$ and Na content) of okra pods, while they suggests that fruit size and genotype should be considered for better end-use of the final product.

Sugars and organic acids composition are presented in Table 3. Sucrose was the main detected sugar in small size fruit of all the genotypes except for cv. "Dwarf Long Green" and "Silver Queen" where fructose and glucose were the most abundant sugars. In larger fruit, sugar composition differed between the studied genotypes, with Greek okra genotypes showing either a balanced content of individual sugars (cv. "Lasithi" and "Pylaea") or higher amounts of sucrose (cv. "Boyati" and "Veloudo"), whereas for foreign genotypes fructose and glucose were the main detected sugars. Moreover, regarding the effect of fruit size on sugar composition, fructose, glucose and total sugars content increased with pod size, while sucrose decreased for most of the genotypes (except for cv. "Pylaea", "Boyati" and "Veloudo"). Longe et al. (1982) have also reported varietal differences in carbohydrate constituents of okra pods of different age and they suggest that carbohydrates either decrease with age or increase and reach a peak at the 4th day after fruit set and then decrease. Similar trends of sucrose content in relation to pod size have been also observed in French beans pods, with full-sized pods having higher sucrose content than half sized, whereas fructose and glucose content increased with pod size (Selan et al., 2014). This difference could be explained by the fact that harvest age coincides with different pod development stage in okra and beans, since okra pods in our study were harvested a few days after fruit set and before seed formation, whereas green beans are harvested at later stages and after seeds have been formed. Sucrose is the main carbon and energy source at early pod development stages, and it is gradually broken down by acid invertase to fructose and glucose whose content starts to increase. With further pod development and up to full pod size, acid invertase activity decreases and the opposite trend is observed (Sung, Sheih, Geiger, \& Black, 1994; VandenLangenberg, Bethke, \& Nienhuis, 2012).

Oxalic and malic acid were the only detected organic acids with significant variation between the tested genotypes being observed (Table 3). In spite of oxalic acid being the main detected organic acid for most of the genotypes (except for cv. "Boyati" and "Veloudo" where malic was the main organic acid), its content did not exceed safe limits, since oxalic acid: calcium ratio was lower than 2.5 (ranged between

Table 2

Composition in sugars and organic acids $\left(\mathrm{g} 100 \mathrm{~g}^{-1} \mathrm{fw}\right)$ of the studied okra fruits (mean \pm SD).

\begin{tabular}{|c|c|c|c|c|c|c|c|c|}
\hline Fruit size & Genotype & $\mathrm{Ca}$ & $\mathrm{Mg}$ & $\mathrm{K}$ & $\mathrm{Na}$ & $\mathrm{Fe}$ & $\mathrm{Zn}$ & Mn \\
\hline \multirow[t]{8}{*}{ Small } & Lasithi & $351 \pm 19 a(a)$ & $61 \pm 6 c(a)$ & $615 \pm 44 a(a)$ & $4.2 \pm 0.1 \mathrm{bc}(\mathrm{a})$ & $0.68 \pm 0.01 \mathrm{a}(\mathrm{a})$ & $0.415 \pm 0.008 \mathrm{a}(\mathrm{a})$ & $0.117 \pm 0.016 \mathrm{c}(\mathrm{b})$ \\
\hline & Pylaea & $311 \pm 18 b(a)$ & $59 \pm 6 c d(a)$ & $474 \pm 28 b(a)$ & $4.4 \pm 0.5 b(a)$ & $0.66 \pm 0.01 b(a)$ & $0.402 \pm 0.006 \mathrm{bc}(\mathrm{a})$ & $0.145 \pm 0.018 \mathrm{~b}(\mathrm{~b})$ \\
\hline & Boyati & $359 \pm 8 \mathrm{a}(\mathrm{b})$ & $87 \pm 1 \mathrm{a}(\mathrm{b})$ & $616 \pm 38 a(a)$ & $8.7 \pm 0.2 \mathrm{a}(\mathrm{a})$ & $0.60 \pm 0.02 c(a)$ & $0.422 \pm 0.012 \mathrm{ab}(\mathrm{a})$ & $0.139 \pm 0.015 \mathrm{~b}(\mathrm{~b})$ \\
\hline & Veloudo & $289 \pm 17 b(b)$ & $76 \pm 4 b(b)$ & $577 \pm 38 a(a)$ & $4.6 \pm 0.1 \mathrm{~b}(\mathrm{~b})$ & $0.54 \pm 0.01 \mathrm{~d}(\mathrm{~b})$ & $0.406 \pm 0.005 \mathrm{bc}(\mathrm{a})$ & $0.139 \pm 0.015 b(b)$ \\
\hline & Choppee & $142 \pm 11 \mathrm{e}(\mathrm{b})$ & $36 \pm 2 f(b)$ & $303 \pm 75 d(a)$ & $4.8 \pm 0.3 \mathrm{~b}(\mathrm{a})$ & $0.67 \pm 0.03 \mathrm{ab}(\mathrm{a})$ & $0.413 \pm 0.008 \mathrm{ab}(\mathrm{a})$ & $0.129 \pm 0.015 b c(b)$ \\
\hline & Dwarf Long Green & $147 \pm 4 \mathrm{e}(\mathrm{b})$ & $51 \pm 1 \mathrm{e}(\mathrm{b})$ & $303 \pm 41 d(a)$ & $3.9 \pm 0.1 \mathrm{bc}(\mathrm{a})$ & $0.64 \pm 0.04 b c(b)$ & $0.410 \pm 0.016 \mathrm{ab}(\mathrm{a})$ & $0.135 \pm 0.023 \mathrm{~b}(\mathrm{~b})$ \\
\hline & Silver Queen & $246 \pm 8 c(a)$ & $58 \pm 1 c d(a)$ & $383 \pm 37 c(a)$ & $4.3 \pm 0.4 \mathrm{bc}(\mathrm{a})$ & $0.65 \pm 0.01 b(a)$ & $0.388 \pm 0.008 \mathrm{c}(\mathrm{b})$ & $0.211 \pm 0.025 \mathrm{a}(\mathrm{b})$ \\
\hline & Clemson Spineless & $201 \pm 10 d(a)$ & $53 \pm 4 d e(a)$ & $341 \pm 45 \mathrm{~cd}(\mathrm{a})$ & $3.3 \pm 0.4 \mathrm{c}(\mathrm{a})$ & $0.67 \pm 0.01 \mathrm{ab}(\mathrm{a})$ & $0.414 \pm 0.020 \mathrm{ab}(\mathrm{a})$ & $0.134 \pm 0.027 \mathrm{bc}(\mathrm{b})$ \\
\hline Fruit size & Genotype & $\mathrm{Ca}$ & $\mathrm{Mg}$ & $\mathrm{K}$ & $\mathrm{Na}$ & $\mathrm{Fe}$ & $\mathrm{Zn}$ & Mn \\
\hline \multirow[t]{8}{*}{ Large } & Lasithi & $200 \pm 14 b c(b)$ & $50 \pm 4 c(b)$ & $493 \pm 95 c(a)$ & $3.9 \pm 0.2 \mathrm{c}(\mathrm{b})$ & $0.69 \pm 0.02 b(a)$ & $0.445 \pm 0.012 \mathrm{a}(\mathrm{a})$ & $0.325 \pm 0.027 \mathrm{a}(\mathrm{a})$ \\
\hline & Pylaea & $223 \pm 13 \mathrm{~b}(\mathrm{~b})$ & $68 \pm 5 b(a)$ & $420 \pm 26 \mathrm{~cd}(\mathrm{a})$ & $4.0 \pm 0.4 \mathrm{c}(\mathrm{a})$ & $0.67 \pm 0.02 b(a)$ & $0.413 \pm 0.010 \mathrm{bc}(\mathrm{a})$ & $0.305 \pm 0.021 \mathrm{abc}(\mathrm{a})$ \\
\hline & Boyati & $393 \pm 18 a(a)$ & $109 \pm 8 \mathrm{a}(\mathrm{a})$ & $676 \pm 59 b(a)$ & $7.2 \pm 0.1 \mathrm{a}(\mathrm{b})$ & $0.56 \pm 0.04 c(a)$ & $0.385 \pm 0.003 \mathrm{de}(\mathrm{b})$ & $0.334 \pm 0.023 a(a)$ \\
\hline & Veloudo & $382 \pm 41 \mathrm{a}(\mathrm{a})$ & $101 \pm 10 \mathrm{a}(\mathrm{a})$ & $836 \pm 261 \mathrm{a}(\mathrm{a})$ & $5.4 \pm 02 b(a)$ & $0.63 \pm 0.05 b c(a)$ & $0.369 \pm 0.021 \mathrm{ef}(\mathrm{b})$ & $0.299 \pm 0.024 \mathrm{abc}(\mathrm{a})$ \\
\hline & Choppee & $189 \pm 7 c(a)$ & $49 \pm 2 c(a)$ & $204 \pm 13 \mathrm{f}(\mathrm{b})$ & $4.1 \pm 0.2 \mathrm{c}(\mathrm{b})$ & $0.29 \pm 0.01 \mathrm{~d}(\mathrm{~b})$ & $0.405 \pm 0.01 \mathrm{~cd}(\mathrm{a})$ & $0.279 \pm 0.015 b c(a)$ \\
\hline & Dwarf Long Green & $231 \pm 7 b(a)$ & $62 \pm 2 b(a)$ & $357 \pm$ 53de(a) & $3.8 \pm 0.2 \mathrm{c}(\mathrm{a})$ & $0.81 \pm 0.02 \mathrm{a}(\mathrm{a})$ & $0.356 \pm 0.010 \mathrm{f}(\mathrm{b})$ & $0.319 \pm 0.041 \mathrm{ab}(\mathrm{a})$ \\
\hline & Silver Queen & $199 \pm 9 b c(b)$ & $49 \pm 2 c(b)$ & $386 \pm 63 d(a)$ & $3.8 \pm 0.1 \mathrm{c}(\mathrm{a})$ & $0.61 \pm 0.01 b c(b)$ & $0.433 \pm 0.010 \mathrm{ab}(\mathrm{a})$ & $0.265 \pm 0.025 \mathrm{c}(\mathrm{a})$ \\
\hline & Clemson Spineless & $155 \pm 17 d(b)$ & $48 \pm 1 c(a)$ & $302 \pm 36 \mathrm{e}(\mathrm{a})$ & $2.8 \pm 0.1 \mathrm{~d}(\mathrm{a})$ & $0.80 \pm 0.11 \mathrm{a}(\mathrm{a})$ & $0.314 \pm 0.009 \mathrm{~g}(\mathrm{~b})$ & $0.270 \pm 0.028 \mathrm{c}(\mathrm{a})$ \\
\hline
\end{tabular}

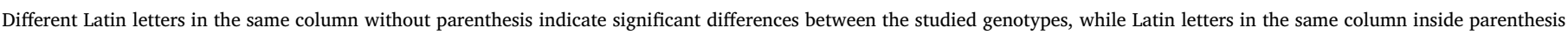
refer to comparisons between fruit sizes of the same genotype according to Tukey's HSD test $(\mathrm{p}=0.05)$.

* S: small size fruit $(3-5 \mathrm{~cm})$; L: Large size fruit $(>7 \mathrm{~cm})$. 

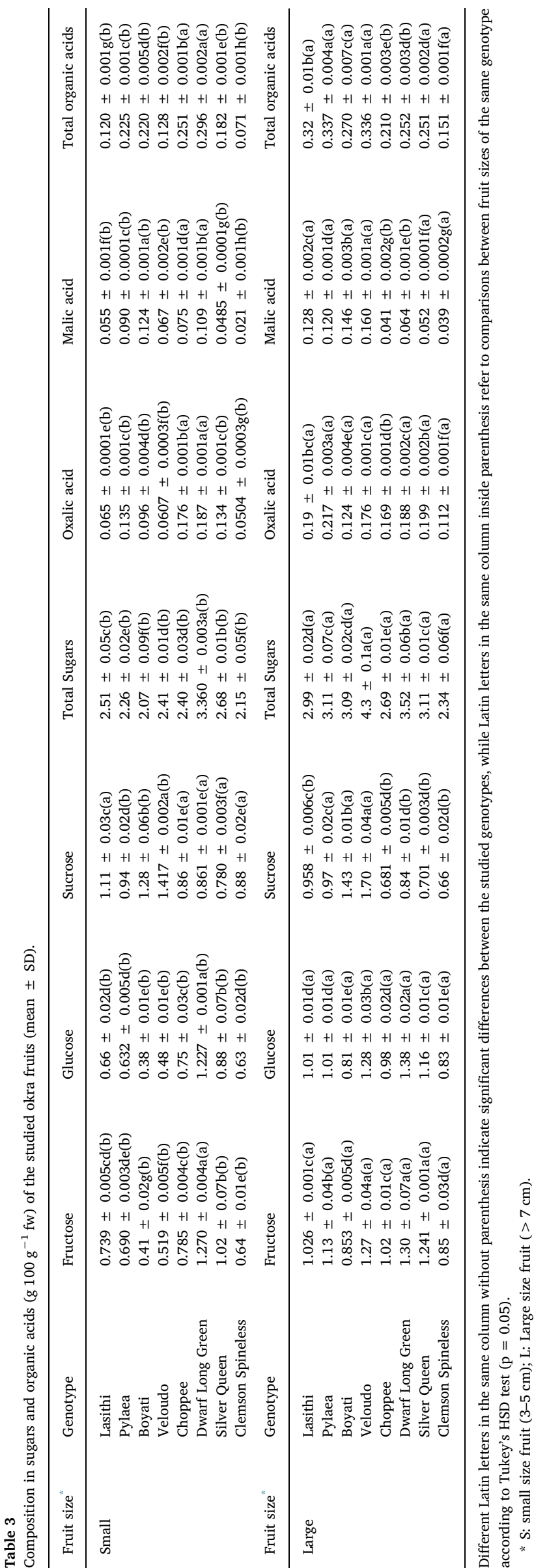

0.21 and 1.27), which is considered the upper threshold for food sources (Guil, Torija, Giménez, Rodríguez-García, \& Himénez, 1996). Moreover, total and individual organic acids increased with pod size, except for genotypes "Choppee" and "Dwarf Long Green", where a decrease was observed for oxalic, malic and total organic acids and malic and total organic acids, respectively. To the best of our knowledge, this is the first report about organic acids content in okra pods in relation to pod size, therefore our results cannot be compared with those of other studies. However, the increase of organic acids content has been associated with fruit ripening in various small fruit (Mahmood, Anwar, Abbas, Boyce, \& Saari, 2012), while Gemede et al. (2016) and Adetuyi and Osagie (2011) observed significant differences in oxalate content between various okra accessions. Similarly to our results, Selan et al. (2014) reported that malic acid either decrease or increase during maturation of French bean pods, depending on the cultivar, while Martínez et al. (1995) observed an increase of malic acid with pod size for two green beans cultivars.

Tocopherols, carotenoids and chlorophyll contents are presented in Table 4. Alpha-tocopherol was the main tocopherol vitamer followed by gamma-tocopherol, whereas no other vitamers were detected. Significant differences were observed between the tested okra genotypes and pod sizes, with small pods of cv. "Dwarf Long Green" having the highest amounts of tocopherol vitamers and total tocopherols, whereas for large pods cv. "Choppee" showed the highest amounts. Moreover, alpha- and total tocopherols increased with pod development only for cv. "Pylaea", "Boyati" and "Choppee", while gamma-tocopherol increased only in pods of cv. "Pylaea". According to Chennupati, Seguin, and Liu (2011), the changes of tocopherols content during soybean development could be attributed to temperature stress and genotype, with different responses between various genotypes. Moreover, Gnayfeed, Daood, Biacs, and Alcaraz (2001) have reported a significant increase of alpha-tocopherol during red pepper ripening, while similar results have been reported by Dhillon et al. (2016) and Saini, Zamany, and Keum (2017) for bitter gourd (Momordica charantia L.) and tomato fruit (Solanum lycopersicum L.), respectively Considering, the antioxidant properties of tocopherols, harvesting at early stages of fruit development is essential for pod quality for most of the studied genotypes, whereas especially for cv. "Pylaea" and "Boyati" which are usually harvested at small size, harvesting fruit at larger size should be considered with care and only if market standards are met.

Significant differences were also observed in carotenoids and chlorophyll content between the studied genotypes, as well as in relation to pod size (Table 4). Beta-carotene was the highest and lowest for cv. "Veloudo" and "Clemson Spineless" for both pod sizes, respectively, whereas the opposite trend was observed for lycopene. Cv. "Boyati" had the highest content of chlorophylls, regardless of pod size, whereas cv. "Choppee" and "Lasithi" had the lowest content of chlorophyll $a$ and b, respectively. The reported values of beta-carotene are within the range or higher than values reported by Gemede et al. (2014) (185 $\mu \mathrm{g} 100 \mathrm{~g}^{-1}$ f.w.) for okra pods, whereas Rai and Balasubramanian (2009) have reported significantly higher values for both carotene and chlorophylls content (10 and $60 \mathrm{mg} 100 \mathrm{~g}^{-1} \mathrm{fw}$, respectively) probably due to differences in genotype and/or pod size at harvest stage. Regarding the effect of pod size on pigments content, for most of the tested genotypes a significant decrease was observed with pod development, with only exception cv. "Boyati" and "Veloudo" where chlorophylls content increased, while lycopene and beta carotene increased or did not change. Martínez et al. (1995) have also reported a decrease of chlorophylls content with pod development in French beans, and they suggest that increased acidity may have severe effects on chlorophyll pigments. However, this was not confirmed in our study as a general trend, since chlorophylls content increase (e.g. cv. "Boyati" and "Veloudo") and was not accompanied with total organic acids content decrease.

Regarding fatty acids composition of okra pods, twenty-four different fatty acids were detected (data not shown), while the most 


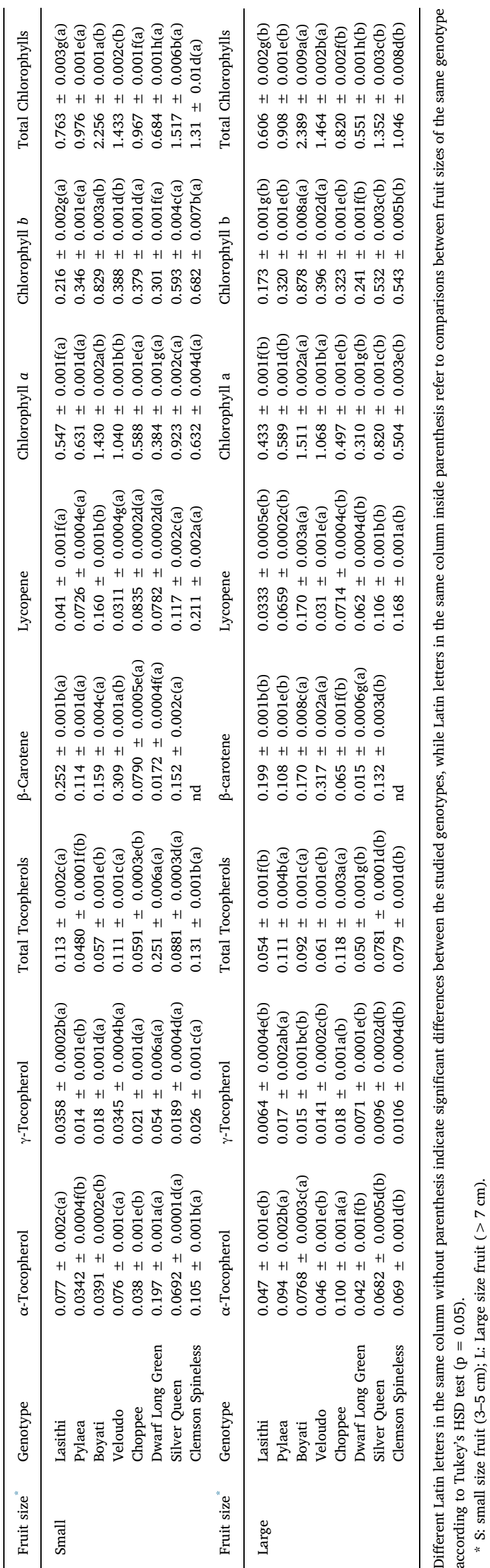

abundant were linoleic (44.36-47.84\%), palmitic (19.3-21.84\%) and alpha-linolenic acid (14.60-20.98\%), followed by oleic, stearic and behenic acid which were detected in lower amounts (Table 5). Individual fatty acids content differed significantly between the tested genotypes for both pod sizes, which also resulted in differences in saturated (SFA), monounsaturated (MUFA) and polyunsaturated fatty acids (PUFA) content. In any case, PUFA/SFA and n-6/n-3 ratios were higher than 0.45 and lower than 4.0, respectively, which both indicate high nutritional value of pods (Guil, Torija, Giménez, \& Rodriguez, 1996). Similar results have been reported by Sami, Lianzhou, Yang, Ma, and Jing (2013) who also identified linoleic, palmitic and alpha-linolenic acid as the main fatty acids in sun-dried okra pods collected from different locations in Egypt, in amounts that differed significantly between the tested genotypes. However, fatty acids composition differed significantly from the present study, indicating that apart from genotype growing conditions may also have an impact on chemical composition of okra fruit. Moreover, fluctuation in fatty acids content during pod development was also observed by Berry (1980) who evaluated fatty acids composition at different harvest stages (5-12 days after anthesis), as well as in mature seeds.

Antioxidant activity differed significantly among the tested genotypes and pod sizes, without however a consistent trend for all the studied assays (Table 6). In particular, for reducing power assay cv. "Clemson Spineless" showed the highest antioxidant activity for both small and large fruit, whereas cv. "Lasithi" presented the lowest antioxidant potential. For DPPH and beta-carotene assays, cv. "Silver Queen" and "Dwarf Long Green" had the highest antioxidant activity for both fruit sizes, respectively, while for TBARS assay "Dwarf Long Green" and "Silver Queen" had the lowest $\mathrm{EC}_{50}$ values for small and large fruit, respectively. Similarly, the effect of fruit size on antioxidant potential depended on genotype and the tested assay, with no specific trends being observed. Ademoyegun, Akin-Idowu, Ibitoye, and Adewuyi (2013) and Ray, Saha, Raychaudhuri, and Chakraborty (2017) who evaluated the antioxidant activity of okra pods with DPPH assay have reported significantly higher $\mathrm{EC}_{50}$ values (approx. 10 and $50 \mathrm{mg} \mathrm{mL}^{-1}$, respectively) comparing to our study, which is probably due to sample preparation (drying of purchased samples at $60{ }^{\circ} \mathrm{C}$ comparing to deep-freezing and freeze drying of fresh harvested samples that was applied in our study) that could reduce antioxidant potency due to loss of antioxidant compounds (Arlai et al., 2012).

\section{Conclusion}

In conclusion, fruit size has a genotype dependent impact on chemical composition and nutritional value of okra pods, while the studied genotypes also presented significant differences in chemical composition of pods. In particular, cv. "Veloudo" had the highest protein, carbohydrates and energy content for both fruit sizes, cv. "Dwarf Long Green" and "Choppee" had the highest tocopherols content in small and large fruit, respectively, while antioxidant activity was highest for cv. "Clemson Spineless" and "Silver Queen" for Reducing Power and DPPH assays, respectively. Moreover, the results of our study show that the common practice of harvesting okra fruit while they still have small size helps to increase nutritional value when the end-product is intended for raw consumption and visual appearance and texture are the first priority for consumer's acceptance. However, the option of harvesting larger fruit should be also considered, since specific genotypes showed different trends for specific compounds, and their fruit could be used for alternatives uses, such as pickles, canned or dried products with increased nutritional value and antioxidant properties.

\section{Acknowledgements}

The authors are grateful to the Foundation for Science and Technology (FCT, Portugal) and FEDER under Programme PT2020 for financial support to CIMO (UID/AGR/00690/2013), A. Fernandes 


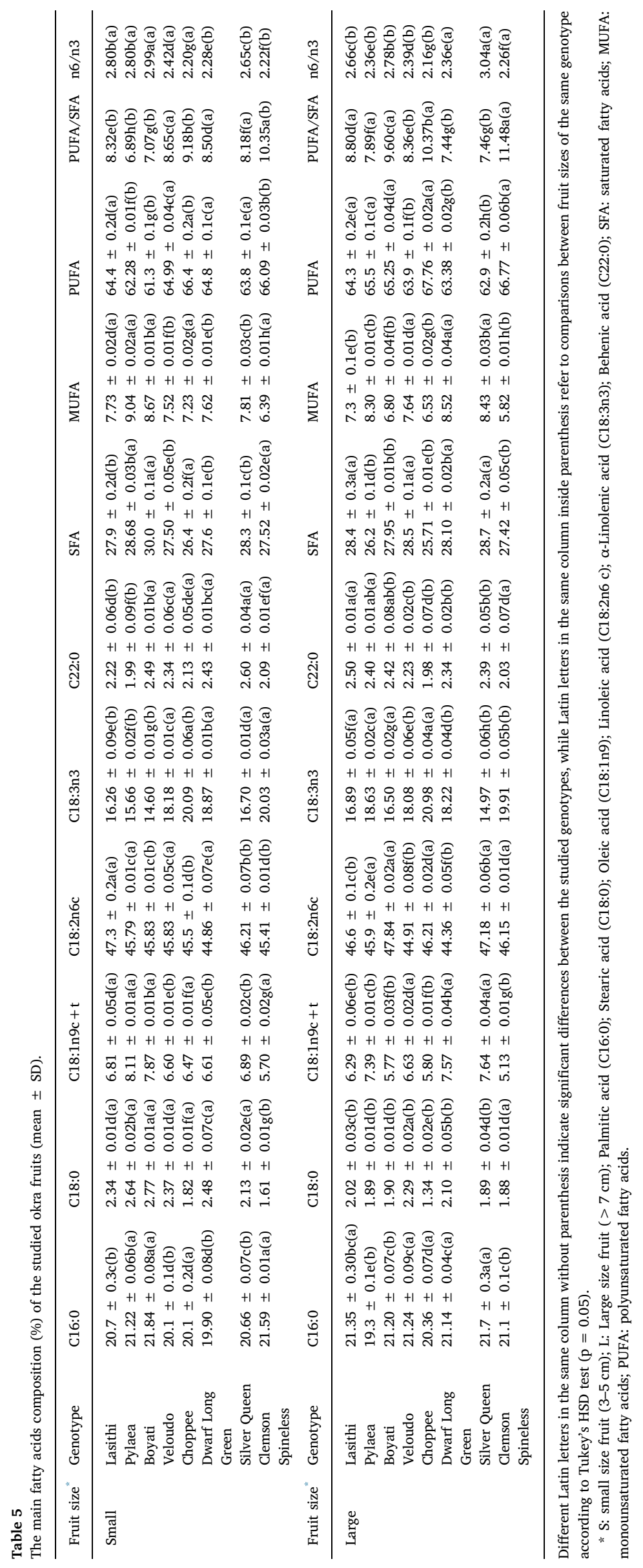


Table 6

Antioxidant properties of the studied okra fruits.

\begin{tabular}{|c|c|c|c|c|c|}
\hline \multirow[t]{2}{*}{ Fruit size $^{*}$} & \multirow[t]{2}{*}{ Genotype } & \multirow{2}{*}{$\begin{array}{l}\text { Reducing power } \\
\text { Ferricyanide/Prussian blue }\left(\mathrm{EC}_{50} ;\right. \\
\mathrm{mg} / \mathrm{mL})\end{array}$} & \multicolumn{2}{|l|}{ Radical scavenging activity } & \multirow{2}{*}{$\begin{array}{l}\text { Lipid peroxidation inhibition } \\
\text { TBARS }\left(\mathrm{EC}_{50} ; \mathrm{mg} / \mathrm{mL}\right)\end{array}$} \\
\hline & & & $\begin{array}{l}\text { DPPH scavenging activity }\left(\mathrm{EC}_{50} \text {; }\right. \\
\mathrm{mg} / \mathrm{mL})\end{array}$ & $\begin{array}{l}\beta \text {-Carotene/linoleate }\left(\mathrm{EC}_{50}\right. \\
\mathrm{mg} / \mathrm{mL})\end{array}$ & \\
\hline \multirow[t]{8}{*}{ Small } & Lasithi & $0.91 \pm 0.01 \mathrm{a}(\mathrm{a})$ & $1.27 \pm 0.01 \mathrm{a}(\mathrm{a})$ & $0.45 \pm 0.01 \mathrm{~b}(\mathrm{~b})$ & $0.142 \pm 0.001 \mathrm{a}(\mathrm{a})$ \\
\hline & Pylaea & $0.79 \pm 0.01 \mathrm{~d}(\mathrm{a})$ & $1.17 \pm 0.03 \mathrm{~b}(\mathrm{a})$ & $0.50 \pm 0.02 \mathrm{a}(\mathrm{a})$ & $0.128 \pm 0.003 \mathrm{~d}(\mathrm{~b})$ \\
\hline & Boyati & $0.64 \pm 0.02 f(b)$ & $1.11 \pm 0.01 \mathrm{c}(\mathrm{b})$ & $0.49 \pm 0.01 \mathrm{a}(\mathrm{b})$ & $0.14 \pm 0.01 \mathrm{a}(\mathrm{b})$ \\
\hline & Veloudo & $0.89 \pm 0.01 b(a)$ & $1.05 \pm 0.01 \mathrm{~d}(\mathrm{a})$ & $0.51 \pm 0.01 \mathrm{a}(\mathrm{a})$ & $0.14 \pm 0.01 \mathrm{abc}(\mathrm{b})$ \\
\hline & Choppee & $0.82 \pm 0.01 \mathrm{c}(\mathrm{a})$ & $1.01 \pm 0.05 \operatorname{de}(a)$ & $0.49 \pm 0.01 \mathrm{ab}(\mathrm{a})$ & $0.141 \pm 0.001 \mathrm{ab}(\mathrm{b})$ \\
\hline & $\begin{array}{l}\text { Dwarf Long } \\
\text { Green }\end{array}$ & $0.68 \pm 0.01 \mathrm{~d}(\mathrm{~b})$ & $0.99 \pm 0.03 e(a)$ & $0.47 \pm 0.01 b(a)$ & $0.126 \pm 0.002 \mathrm{~d}(\mathrm{~b})$ \\
\hline & Silver Queen & $0.684 \pm 0.001 \mathrm{~d}(\mathrm{~b})$ & $0.66 \pm 0.03 f(a)$ & $0.47 \pm 0.01 \mathrm{ab}(\mathrm{a})$ & $0.135 \pm 0.003 c(a)$ \\
\hline & $\begin{array}{l}\text { Clemson } \\
\text { Spineless }\end{array}$ & $0.636 \pm 0.003 f(a)$ & $1.13 \pm 0.04 \mathrm{bc}(\mathrm{a})$ & $0.50 \pm 0.01 \mathrm{a}(\mathrm{a})$ & $0.136 \pm 0.001 b c(b)$ \\
\hline Fruit size & Genotype & $\begin{array}{l}\text { Ferricyanide/Prussian blue }\left(\mathrm{EC}_{50}\right. \\
\mathrm{mg} / \mathrm{mL})\end{array}$ & $\begin{array}{l}\text { DPPH scavenging activity }\left(\mathrm{EC}_{50}\right. \\
\mathrm{mg} / \mathrm{mL})\end{array}$ & $\begin{array}{l}\beta \text {-Carotene/linoleate }\left(\mathrm{EC}_{50}\right. \\
\mathrm{mg} / \mathrm{mL})\end{array}$ & TBARS $\left(\mathrm{EC}_{50} ; \mathrm{mg} / \mathrm{mL}\right)$ \\
\hline \multirow[t]{8}{*}{ Large } & Lasithi & $0.843 \pm 0.002 \mathrm{a}(\mathrm{b})$ & $0.84 \pm 0.01 \mathrm{~d}(\mathrm{a})$ & $0.61 \pm 0.02 \mathrm{a}(\mathrm{a})$ & $0.142 \pm 0.004 \mathrm{bc}(\mathrm{a})$ \\
\hline & Pylaea & $0.8 \pm 0.1 \mathrm{~b}(\mathrm{a})$ & $1.06 \pm 0.01 \mathrm{~b}(\mathrm{~b})$ & $0.50 \pm 0.01 \mathrm{~b}(\mathrm{a})$ & $0.134 \pm 0.002 \mathrm{de}(\mathrm{a})$ \\
\hline & Boyati & $0.869 \pm 0.005 \mathrm{a}(\mathrm{a})$ & $1.18 \pm 0.02 \mathrm{a}(\mathrm{a})$ & $0.50 \pm 0.01 \mathrm{~b}(\mathrm{a})$ & $0.15 \pm 0.01 \mathrm{a}(\mathrm{a})$ \\
\hline & Veloudo & $0.72 \pm 0.01 \mathrm{~cd}(\mathrm{~b})$ & $1.04 \pm 0.02 b(a)$ & $0.48 \pm 0.01 \mathrm{~cd}(\mathrm{~b})$ & $0.147 \pm 0.001 \mathrm{ab}(\mathrm{a})$ \\
\hline & Choppee & $0.75 \pm 0.01 \mathrm{bc}(\mathrm{b})$ & $0.91 \pm 0.01 \mathrm{c}(\mathrm{b})$ & $0.49 \pm 0.01 b c(a)$ & $0.146 \pm 0.002 \mathrm{ab}(\mathrm{a})$ \\
\hline & $\begin{array}{l}\text { Dwarf Long } \\
\text { Green }\end{array}$ & $0.71 \pm 0.01 \mathrm{~d}(\mathrm{a})$ & $0.73 \pm 0.02 \mathrm{e}(\mathrm{b})$ & $0.46 \pm 0.02 \mathrm{~d}(\mathrm{a})$ & $0.136 \pm 0.003 \mathrm{de}(\mathrm{a})$ \\
\hline & Silver Queen & $0.720 \pm 0.003 \mathrm{~cd}(\mathrm{a})$ & $0.7 \pm 0.1 \mathrm{f}(\mathrm{a})$ & $0.47 \pm 0.01 \mathrm{~cd}(\mathrm{a})$ & $0.132 \pm 0.005 \mathrm{e}(\mathrm{a})$ \\
\hline & $\begin{array}{l}\text { Clemson } \\
\text { Spineless }\end{array}$ & $0.636 \pm 0.003 \mathrm{e}(\mathrm{a})$ & $0.81 \pm 0.03 \mathrm{~d}(\mathrm{~b})$ & $0.49 \pm 0.02 b c(a)$ & $0.139 \pm 0.001 \mathrm{~cd}(\mathrm{a})$ \\
\hline
\end{tabular}

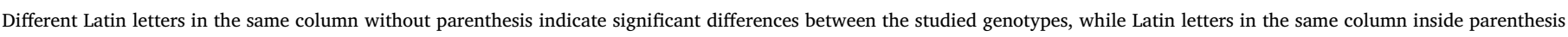
refer to comparisons between fruit sizes of the same genotype according to Tukey's HSD test ( $\mathrm{p}=0.05)$.

* S: small size fruit $(3-5 \mathrm{~cm})$; L: Large size fruit $(>7 \mathrm{~cm})$.

(SFRH/BPD/114753/2016) grant and L. Barros contract.

\section{References}

Ademoyegun, O. T., Akin-Idowu, P. E., Ibitoye, D. O., \& Adewuyi, G. O. (2013). Phenolic contents and free radical scavenging activity in some leafy vegetables. International Journal of Vegetable Science, 19, 126-137. http://dx.doi.org/10.1080/19315260. 2012.677943

Adetuyi, F., \& Osagie, A. (2011). Nutrient, antinutrient, mineral and zinc bioavailability of okra Abelmoschus esculentus (L) Moench variety. American Journal of Food and Nutrition, 1(2), 49-54. http://dx.doi.org/10.5251/ajfn.2011.1.2.49.54.

AOAC (2016). In W. Horwitz, \& G. Latimer (Eds.). Official methods of analysis of AOAC International(20th ed.). Gaithersburg: MD: AOAC International.

Arlai, A., Nakkong, R., Samjamin, N., \& Sitthipaisarnkun, B. (2012). The effects of heating on physical and chemical constitutes of organic and conventional okra. Procedia Engineering, 32, 38-44. http://dx.doi.org/10.1016/j.proeng.2012.01.1234.

Atawodi, S., Atawodi, J., Idakwo, G., Pfundstein, B., Haubner, R., Wurtele, G., ... Owen, R. (2009). Polyphenol composition and antioxidant potential of Hibiscus esculentus L. fruit cultivated in Nigeria. Journal of Medicinal Food, 12(6), 1316-1320.

Barros, L., Pereira, E., Calhelha, R. C., Dueñas, M., Carvalho, A. M., Santos-Buelga, C., \& Ferreira, I. C. F. R. (2013). Bioactivity and chemical characterization in hydrophilic and lipophilic compounds of Chenopodium ambrosioides L. Journal of Functional Foods, 5(4), 1732-1740. http://dx.doi.org/10.1016/j.jff.2013.07.019.

Barros, L., Pereira, C., \& Ferreira, I. C. F. R. (2013). Optimized analysis of organic acids in edible mushrooms from portugal by ultra fast liquid chromatography and photodiode array detection. Food Analytical Methods, 6(1), 309-316. http://dx.doi.org/10.1007/ s12161-012-9443-1.

Berry, S. K. (1980). The fatty acid composition and cyclopropene fatty acid content of the maturing okra (Hibiscus esculentus L.) fruits. Pertanika, 3(2), 82-86.

Çalişir, S., Özcan, M., Haciseferoğullari, H., \& Yildiz, M. U. (2005). A study on some physico-chemical properties of Turkey okra (Hibiscus esculenta L.) seeds. Journal of Food Engineering, 68(1), 73-78. http://dx.doi.org/10.1016/j.jfoodeng.2004.05.023.

Camciuc, M., Deplagne, M., Vilarem, G., \& Gaset, A. (1998). Okra - Abelmoschus esculentus L. (Moench.) a crop with economic potential for set aside acreage in France. Industrial Crops and Products, 7(2-3), 257-264. http://dx.doi.org/10.1016/S09266690(97), 00056-3.

Chennupati, P., Seguin, P., \& Liu, W. (2011). Effects of high temperature stress at different development stages on soybean isoflavone and tocopherol concentrations. Journal of Agricultural and Food Chemistry, 59(24), 13081-13088. http://dx.doi.org/10.1021/ jf2037714.

Dhillon, N., Lin, C., Sun, Z., Hanson, P., Ledesma, D., Habicht, S., \& Yang, R. (2016) Varietal and harvesting stage variation in the content of carotenoids, ascorbic acid and tocopherols in the fruit of bitter gourd (Momordica charantia L.). Plant Genetic Resources. http://dx.doi.org/10.1017/S147926211500057X.

Dos Santos, I. F., Dos Santos, A. M. P., Barbosa, U. A., Lima, J. S., Dos Santos, D. C., \&
Matos, G. D. (2013). Multivariate analysis of the mineral content of raw and cooked okra (Abelmoschus esculentus L.). Microchemical Journal, 110, 439-443. http://dx. doi.org/10.1016/j.microc.2013.05.008.

Gemede, H. F., Haki, G. D., Beyene, F., Woldegiorgis, A. Z., \& Rakshit, S. K. (2016). Proximate, mineral, and antinutrient compositions of indigenous Okra (Abelmoschus esculentus) pod accessions: Implications for mineral bioavailability. Food Science and Nutrition, 4(2), 223-233. http://dx.doi.org/10.1002/fsn3.282.

Gemede, H. F., Ratta, N., Haki, G. D., \& Woldegiorgis, A. Z. (2014). Nutritional quality and health benefits of Okra (Abelmoschus esculentus): A review. Food Science and Quality Management, 33, 87-97. http://dx.doi.org/10.4172/2157-7110.1000458.

Ghori, M. U., Alba, K., Smith, A. M., Conway, B. R., \& Kontogiorgos, V. (2014). Okra extracts in pharmaceutical and food applications. Food Hydrocolloids, 42(P3), 342-347. http://dx.doi.org/10.1016/j.foodhyd.2014.04.024.

Gnayfeed, M. H., Daood, H. G., Biacs, P. A., \& Alcaraz, C. F. (2001). Content of bioactive compounds in pungent spice red pepper (paprika) as affected by ripening and genotype. Journal of the Science of Food and Agriculture, 81(15), 1580-1585. http://dx. doi.org/10.1002/jsfa.982.

Guil, J. L., Torija, M. E., Giménez, J. J., \& Rodriguez, I. (1996). Identification of fatty acids in edible wild plants by gas chromatography. Journal of Chromatography A, 719, 229-235. http://dx.doi.org/10.1007/s12161-008-9063-y.

Guil, J. L., Torija, M. E., Giménez, J. J., Rodríguez-García, I., \& Himénez, A. (1996). Oxalic acid and calcium determination in wild edible plants. Journal of Agricultural and Food Chemistry, 44(7), 1821-1823. http://dx.doi.org/10.1021/jf950472a.

Kamalesh, P., Subrata, D., Asraf, A. K., \& Pranabesh, C. (2016). Phytochemical in vestigation and hypoglycaemic effect of Abelmoschus esculentus. Research Journal of Pharmacy and Technology, 9(2), 162-164.

Koutsos, T. V., Koutsika-Sotiriou, M., Gouli-vavdinoudi, E., \& Tertivanidis, K. (2000). Study of the genetic relationship of Greek okra cultivars (Abelmoschus esculentus L.) by using agronomic traits, heterosis and combining ability. Journal of Vegetable Crop Production, 6(1), 25-35. http://dx.doi.org/10.1300/J068v06n01.

Longe, O. G., Fetuga, B. L., \& Aken'ova, M. E. (1982). Changes in the composition and carbohydrate constituents of okra (Abelmoschus esculentus, Linn.) with age. Food Chemistry, 8(1), 27-32. http://dx.doi.org/10.1016/0308-8146(82)90054-1.

Mahmood, T., Anwar, F., Abbas, M., Boyce, M. C., \& Saari, N. (2012). Compositional variation in sugars and organic acids at different maturity stages in selected small fruits from Pakistan. International Journal of Molecular Sciences, 13(2), 1380-1392. http://dx.doi.org/10.3390/ijms13021380.

Makhadmeh, I. M., \& Ereifej, K. I. (2004). Geometric characteristics and chemical composition of okra (Hibiscus esculentus L.) grown under semi-arid conditions. International Journal of Food Properties, 7(1), 83-90. http://dx.doi.org/10.1081/JFP120022983.

Martínez, C., Ros, G., Periago, M. J., López, G., Ortuño, J., \& Rincón, F. (1995). Physicochemical and sensory quality criteria of green beans (Phaseolus vulgaris, L.). Lebensmittel-Wissenschaft Und-Technologie, 28(5), 515-520. http://dx.doi.org/10. 1006/fstl.1995.0086.

Mishra, N., Kumar, D., \& Rizvi, S. I. (2013). Protective effect of Abelmoschus esculentus 
against alloxan-induced diabetes in Wistar strain rats. Journal of Dietary Supplements, 13(6), 634-646.

Nagata, M., \& Yamashita, I. (1992). Simple method for simultaneous determination of chlorophyll and carotenoids in tomato fruit. Nippon Shokuhin Kogyo Gakkaishi, 39(10), 925-928.

Olivera, D. F., Mugridge, A., Chaves, A. R., Mascheroni, R. H., \& Viña, S. Z. (2012). Quality attributes of okra (Abelmoschus esculentus L. Moench) pods as affected by cultivar and fruit size. Journal of Food Research, 1(4), 224-235. http://dx.doi.org/10. 5539/jfr.v1n4p224.

Piloo, N., \& Kabir, J. (2011). Effect of age of harvest on fruit quality of okra (Abelmoschus esculentus L.). Journal of Environmental Research And Development, 5(3), 615-622.

Rai, D. R., \& Balasubramanian, S. (2009). Qualitative and textural changes in fresh okra pods (Hibiscus esculentus L.) under modified atmosphere packaging in perforated film packages. Food Science and Technology International, 15(2), 131-138. http://dx. doi.org/10.1177/1082013208106206.

Ray, S., Saha, S. K., Raychaudhuri, U., \& Chakraborty, R. (2017). Preparation of okraincorporated dhokla and subsequent analysis of nutrition, antioxidant, color, moisture and sensory profile. Journal of Food Measurement and Characterization, 11(2), 639-650. http://dx.doi.org/10.1007/s11694-016-9433-x.

Saini, R. K., Zamany, A. J., \& Keum, Y.-S. (2017). Ripening improves the content of carotenoid, $\alpha$-tocopherol, and polyunsaturated fatty acids in tomato (Solanum lycopersicum L.) fruits. 3 Biotech, 7(1), 43. http://dx.doi.org/10.1007/s13205-0170666-0.

Sami, R., Lianzhou, J., Yang, L., Ma, Y., \& Jing, J. (2013). Evaluation of fatty acid and amino acid compositions in Okra (Abelmoschus esculentus) grown in different geographical locations. Biomed Research International, 2013. http://dx.doi.org/10.1155/ 2013/574283 6 pages, Article ID 574283.

Selan, M., Kastelec, D., Jakopič, J., Veberič, R., Mikulič-Petkovšek, M., \& Kacjan-Maršić, N. (2014). Hail net cover, cultivar and pod size influence the chemical composition of dwarf French bean. Scientia Horticulturae, 175, 95-104. http://dx.doi.org/10.1016/j. scienta.2014.06.002.

Siemonsma, J. S. (1982). West african okra - Morphological and cytogenetical indications for the existence of a natural amphidiploid of Abelmoschus esculentus (L.) Moench and A. manihot (L.) Medikus. Euphytica, 31(1), 241-252. http://dx.doi.org/10.1007/ BF00028327.

Sung, S. S., Sheih, W. J., Geiger, D. R., \& Black, C. C. (1994). Growth, sucrose synthase, and invertase activities of developing Phaseolus vulgaris L. fruits. Plant, Cell \& Environment, 17(4), 419-426. http://dx.doi.org/10.1111/j.1365-3040.1994. tb00310.x.

VandenLangenberg, K. M., Bethke, P. C., \& Nienhuis, J. (2012). Patterns of fructose, glucose, and sucrose accumulation in Snap and dry bean (Phaseolus vulgaris) pods. HortScience, 47(7), 874-878. 